\title{
Survival of Colletotrichum acutatum in Soil and Plant Debris of Leatherleaf Fern
}

\author{
D. J. Norman and J. O. Strandberg, Plant Pathology Department, University of Florida, IFAS, Central Florida Re- \\ search and Education Center, 2807 Binion Rd., Apopka 32703
}

\begin{abstract}
Norman, D. J., and Strandberg, J. O. 1997. Survival of Colletotrichum acutatum in soil and plant debris of leatherleaf fern. Plant Dis. 81:1177-1180.

Leatherleaf fern anthracnose is incited by a new pathotype of Colletotrichum acutatum. Fern anthracnose appeared in Florida in 1993, has spread rapidly, and produces losses that approach $100 \%$ in some ferneries. To help develop recommendations for control and management of fern anthracnose, the survival of the pathogen in soil and diseased plant material and on clothing was investigated in laboratory and field experiments. Survival of conidia, sclerotia, and conidia in infected leaf debris was studied in soil maintained at five soil moisture levels. Survival of conidia and sclerotia declined rapidly under moist conditions $(\geq 12 \%$ moisture, vol/wt), but under dry conditions, viable conidia could be detected up to 12 months after incorporation into soil. Similar results were obtained in field experiments in which infected leaf debris was buried in soil. Viable conidia were recovered for up to 3 months in leaf debris stored under laboratory conditions. Conidia applied to denim fabric were recovered up to 5 weeks after application. This indicated that contaminated clothing could transport conidia effectively within and between ferneries. Inoculating ferns with dilutions of conidia demonstrated that at least 100 conidia per $\mathrm{ml}$ is required to infect and colonize leatherleaf fern leaves. This threshold provides an estimate of levels of conidia populations likely to result in disease and levels that sanitation or cultural practices must exceed to be effective management methods.
\end{abstract}

Additional keywords: cut foliage, fungus

Leatherleaf fern (Rumohra adiantiformis (G. Forster) Ching) is the largest cut foliage crop in the United States; the estimated 1993 wholesale value was $\$ 70$ million (18). Leatherleaf fern fronds are used in floral arrangements. Most are used domestically (North America), but about 25\% are shipped to Europe and Japan. About 2,860 ha of leatherleaf fern is grown in Florida. Smaller amounts are grown in California, Hawaii, Georgia, Louisiana, and Texas. Leatherleaf fern is a perennial crop, so production occurs throughout the year. The ferns are grown under $73 \%$ shade cloth or oak trees.

Fungal diseases incited by Cylindrocladium, Pythium, and Rhizoctonia spp. can affect leatherleaf fern $(4,14)$, but fungicides can control these diseases and minimize losses. A new disease of leatherleaf fern (fern anthracnose) first appeared in Florida in 1993 (15). A similar disease was reported a few years earlier on plantings in Costa Rica (4). The fungal pathogen has been identified as a pathotype of Colletotrichum acutatum J.H. Simmonds. C. acu-

Corresponding author: D. J. Norman

E-mail: djn@icon.apk.ufl.edu

Florida Agricultural Experiment Station Journal Series R-05704.

Accepted for publication 11 July 1997.

Publication no. D-1997-0807-01R

(C) 1997 The American Phytopathological Society tatum also has been described as a pathogen of strawberry $(7,8,11)$, citrus $(22)$, flowering dogwood (3), peach (1), apple (1), pecan (1), and black gum (2). On leatherleaf fern, $C$. acutatum infects young, immature fronds and results in a black necrosis and deformation of leaflets that makes all infected fronds unmarketable. Severely infected fern plantings appear as if burned due to extensive black necrosis on leaves.

We have observed production losses attributed to C. acutatum approaching $100 \%$ in some ferneries. Since its appearance in 1993, the pathogen has spread rapidly, and as of December 1994, five counties in Florida have reported the occurrence of the pathogen in their ferneries. We estimate (16) that one-half of the land in leatherleaf production has been infested.

The ecology and survival of $C$. coccodes (9), C. graminicola (19), C. truncatum (12), and $C$. lindemuthianum $(6,17)$ in soil have been studied. The ecology of $C$. acutatum, which affects strawberry, pine, and citrus production $(7,8,13,20-22)$, also has been studied. However, because the disease incited by $C$. acutatum on leatherleaf fern is new to Florida, no substantial research has been completed on the ecology of this organism and its relationship to leatherleaf fern. Our study was undertaken to determine the potential for survival of $C$. acutatum in soil and plant debris within leatherleaf ferneries and the ability of surviving inoculum to incite disease.

\section{MATERIALS AND METHODS}

Infectivity tests. We determined the number of conidia necessary for infection and disease development on leatherleaf fern by spraying various concentrations of conidia on leatherleaf fern leaves. Conidia were harvested from cultures after $72 \mathrm{~h}$ of growth on potato dextrose agar (PDA) under GrowLux fluorescent light (Sylvania Inc., Danvers, MA), 12-h day/night cycle, at $24^{\circ} \mathrm{C}$, were diluted in sterile distilled water (SDW) to $1 \times 10^{7}$ conidia per $\mathrm{ml}$, and were diluted serially for inoculations. Ten plants were inoculated with each dilution, and a SDW treatment was used as a control. Inoculum was applied with a hand-held sprayer to fern plants growing in $450-\mathrm{cm}^{3}$ pots. Leaves were sprayed to runoff. Plants were placed in plastic bags for $24 \mathrm{~h}$ to maintain high humidity and placed in a glass house in randomized complete blocks. After 2 weeks, plants were evaluated for disease development, and the presence and reproduction of C. acutatum was confirmed. This experiment was repeated two additional times, and the results were averaged.

Semiselective medium. Naturally occurring populations of fungi and bacteria in soil make studies of specific organisms found in low numbers especially difficult. To develop a semiselective medium that could be used both with controlled environment and field samples, a selective marker was needed. The fungicide benomyl previously had been used extensively in leatherleaf fern production and did not control fern anthracnose. Thus, C. acutatum was expected to be tolerant to it. Induced resistance to benomyl is thought to arise from a single gene mutation and is easily induced and stable (10). However, resistance of $C$. acutatum to benomyl is considered by some to be natural and not the result of selection pressure (1). Benomyl has been included in semiselective media developed in other studies for isolation of Colletotrichum spp. from soil $(5,7,9)$.

Tolerance of $C$. acutatum isolates from leatherleaf fern to benomyl was evaluated according to radial growth of fungal colonies and conidial germination on benomyl-amended PDA. Radial growth of four isolates from four ferneries was measured on PDA and PDA amended with 5, 50, 100,500 , and 1,000 $\mu \mathrm{g}$ of benomyl (Benlate WP, 50 a.i.) per ml. Three plugs from a 2-day-old culture growing on PDA were removed with a 4-mm cork borer and placed equidistant on 9-cm-diameter petri plates containing $20 \mathrm{ml}$ of media; two replicate plates were used for each treatment. Plates 
were incubated under Gro-Lux fluorescent lights, 12-h day/night cycle. Radial growth of the six colonies in each treatment was measured daily for 5 days. Treatment means were compared with Tukey's least significant difference (LSD) test.

The effect of benomyl on germination of conidia of $C$. acutatum was examined on 10 isolates obtained from 10 separate ferneries. Conidial suspensions $\left(1 \times 10^{5}\right.$ conidia per $\mathrm{ml}$ ) from 48-h-old PDA cultures were spread on 9-cm-diameter petri plates containing $20 \mathrm{ml}$ of PDA or PDA amended with $1,000 \mu \mathrm{g}$ of benomyl per ml. Cultures were incubated as described previously. After 20 h, 300 conidia were examined under magnification, and the percent germination was determined. This experiment was repeated three times. Means were compared with Tukey's LSD test. Based on observable inhibition of competitive soil fungi, a concentration of $50 \mu \mathrm{g}$ of benomyl per $\mathrm{ml}$ was selected for all subsequent soil assays and field work. Chlortetracycline $(100 \mu \mathrm{g} / \mathrm{ml})$ was added to limit bacterial growth. When $C$. acutatum was grown on this semiselective medium under fluorescent lights, colonies turned a bright salmon orange and were easily identifiable.

Survival of $C$. acutatum in soil and plant debris. Sandy soil ( $\mathrm{pH}$ 6.9) was collected from a fernery that was not infested with $C$. acutatum, air-dried, and sieved through a soil screen (1.7-mm opening) to remove large organic particles. Sieved, airdried soil (100 g) was placed in plastic Magenta (Chicago) vessels, $7.2 \times 7.2 \times 9.6$ $\mathrm{cm}$, with plastic lids. To simulate field conditions, five soil moisture contents that ranged from air-dried to water-saturated were examined. Conidia of $C$. acutatum isolate 95-39 (previously used in benomyl sensitivity testing) were harvested from 48-h-old PDA cultures and suspended in SDW. Concentrations were adjusted with

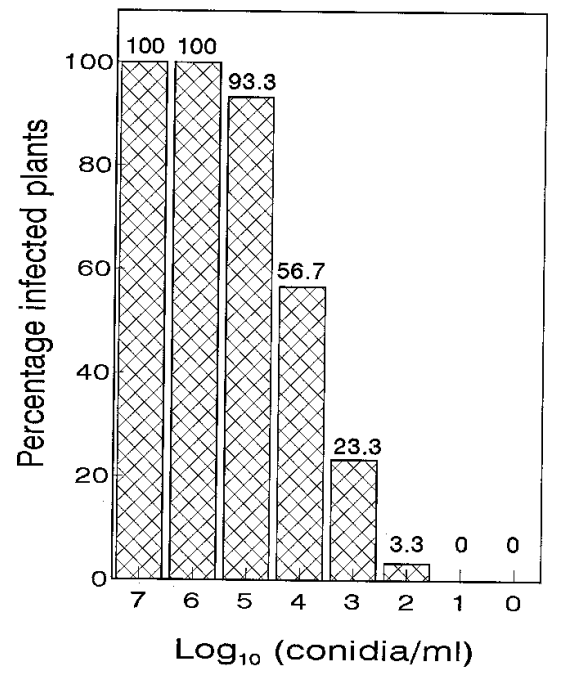

Fig. 1. Percentage of leatherleaf fern plants infected by Colletotrichum acutatum after inoculation with suspensions containing different concentrations of conidia. the aid of a hemacytometer to $8.5 \times 10^{6}$ conidia per $\mathrm{ml}$. Spore suspension $(1 \mathrm{ml})$ was added to vessels containing $100 \mathrm{~g}$ of soil and mixed by hand. Soil moistures were adjusted with SDW to desired levels. The soil was hydrated (based on oven dry weights, vol/wt) to $1,3,6,12(-2.5 \mathrm{kPa})$, or $24 \%$ moisture content. The vessels were sealed and placed in an incubator at $25^{\circ} \mathrm{C}$. SDW was added as needed to maintain a constant level of soil moisture. Each treatment was replicated three times, and each experiment was repeated at least once. For assay, 1-g soil subsamples were removed at weekly intervals for 8 weeks, then at 3week intervals until viable conidia were no longer detected. Each subsample was suspended in $10 \mathrm{ml}$ of SDW, mixed, diluted in SDW to appropriate dilutions, and $0.5 \mathrm{ml}$ of the dilution was spread on plates of semiselective media. Cultures were incubated as previously described, and salmonorange colonies were counted after $72 \mathrm{~h}$ of growth. To confirm that colonies observed on selective media were $C$. acutatum and that they maintained pathogenicity, $10 \mathrm{col}-$ onies ( 2 from each soil moisture treatment) were selected from the subsamples taken $\geq 29$ weeks after incorporating spore suspensions into soil. These isolates were purified, grown on PDA, and spray-inoculated on leatherleaf fern plants $\left(1 \times 10^{7}\right.$ conidia per $\mathrm{ml}$ ) as described for infectivity tests.

To examine survival of $C$. acutatum in diseased leaf debris incorporated into soil, diseased fern fronds were collected, airdried, and chopped into small pieces $(0.1$ to $\left.0.5 \mathrm{~cm}^{2}\right)$. Samples (1 $\mathrm{g}$ ) of chopped leaves were added to $100 \mathrm{~g}$ of sieved soil in Magenta vessels and adjusted to the five previously specified soil moistures. Treatments were replicated three times. Samples were obtained and evaluated as described

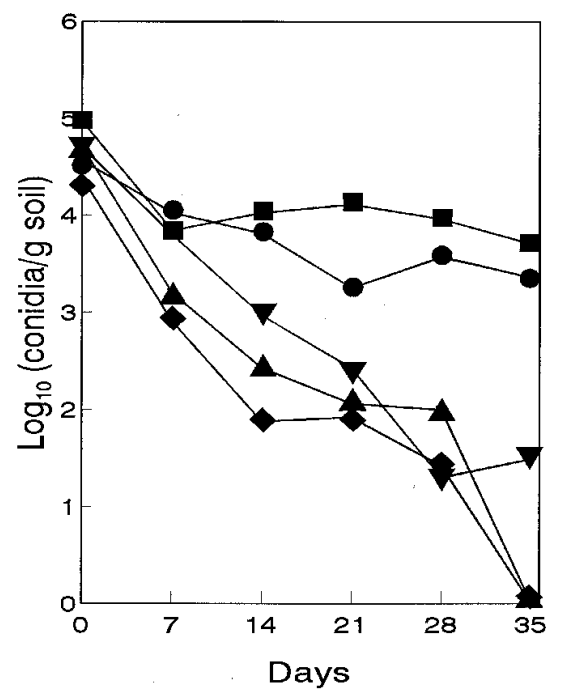

Fig. 2. Number of viable Colletotrichum acutatum conidia recovered from soil maintained in the laboratory at $25^{\circ} \mathrm{C}$ at $1(\mathbf{\square}), 3(\bullet), 6(\boldsymbol{\nabla})$, $12(\boldsymbol{\Delta})$, and $24 \%(\bullet)$ soil moisture over a $36-$ day period. previously. The vessels were maintained in the laboratory at $25^{\circ} \mathrm{C}$.

Survival in leaf debris of $C$. acutatum was examined in 1-g portions of chopped, infected, leatherleaf fronds placed in plastic Magenta vessels. Three replicate vessels were used for each of two treatments, in which leaves were either left dried or moistened with $2 \mathrm{ml}$ of SDW. Subsamples $(0.1 \mathrm{~g})$ of leaf debris were removed at weekly intervals for 8 weeks, diluted in SDW, plated on benomyl-amended PDA, and populations of $C$. acutatum were measured.

To study the survival of sclerotia in soil, we spread $0.5 \mathrm{ml}$ of conidial suspension $\left(1 \times 10^{6}\right.$ conidia per $\left.\mathrm{ml}\right)$ on 9 -cm-diameter acidified PDA plates (PDA supplemented with lactic acid at $0.25 \mathrm{ml} /$ liter). Plates were incubated for 1 month under conditions described previously, and the contents of 18 plates were ground in a blender with $300 \mathrm{ml}$ of SDW. The agar-fungal mixture was rinsed through soil sieves with 250- and 90- $\mu \mathrm{m}$ openings. Sclerotia trapped in the smaller sieve were repeatedly washed with distilled water until no conidia could be observed in the rinsate under microscopic examination. Sclerotia were centrifuged at $5,000 \mathrm{rpm}$ $(9,000 \times g)$ for $10 \mathrm{~min}$, and the liquid-agar supernatant was decanted. Aliquots of the sclerotium pellet $(0.5 \mathrm{~g})$ were added to $100 \mathrm{~g}$ of sieved fern soil in Magenta vessels (calculated as $6 \times 10^{3}$ sclerotia per $g$ of soil). Treatments were replicated three times, and samples were plated on amended PDA and evaluated as described previously.

To compare controlled-environment results with survival of $C$. acutatum in the field, three small shade structures $(1 \times 1 \mathrm{~m}, 70 \%$ shade) were constructed in an open field. Overhead irrigation was supplied to maintain moisture levels above $4 \%$ soil moisture, as suggested for fern production. To maintain this level of soil moisture, tensi-

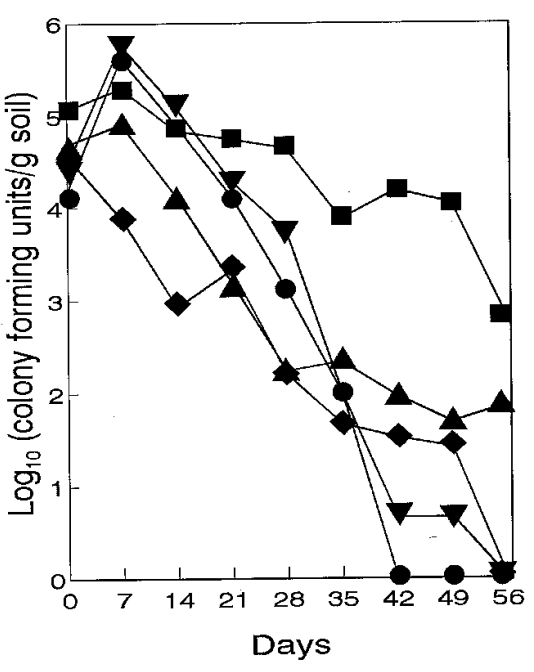

Fig. 3. Number of Colletotrichum acutatum $\mathrm{CFU}$ recovered from diseased leaf debris incorporated into soil maintained at $25^{\circ} \mathrm{C}$ in the laboratory at $1(\boldsymbol{\square}), 3(\bullet), 6(\nabla), 12(\boldsymbol{\Delta})$, and $24 \%(\bullet)$ soil moisture over a 56-day period. 
ometers connected to a data logger were used to monitor soil moisture at a depth of $3 \mathrm{~cm}$. Infected fern fronds were chopped as described previously, and 1-g samples were placed in $2.5 \times 5-\mathrm{cm}$ nylon mesh bags. Thirteen bags were buried $3 \mathrm{~cm}$ deep in each shade structure. Bags were recovered from each structure at 7-day intervals for 4 weeks and thereafter every 3 weeks until $C$. $a c u$ tatum could not be detected. Samples were processed and evaluated as described previously. This study was conducted from July through November, when air temperatures ranged from 37 to $2^{\circ} \mathrm{C}$, respectively.

Survival of $C$. acutatum conidia on clothing. Concentrations as high as 270 viable conidia per $\mathrm{cm}^{2}$ of denim fabric were recovered from fern harvesters during a 5-h harvesting period (data not shown). To test the ability of these $C$. acutatum conidia to survive on clothing, a spore suspension of $1 \times 10^{6}$ conidia per $\mathrm{ml}$ was sprayed on cotton denim fabric. The fabric was air-dried, cut into $1-\mathrm{cm}^{2}$ sections, and stored in vessels at $25^{\circ} \mathrm{C}$. Once weekly, three $1-\mathrm{cm}^{2}$ sections of cloth were removed, placed in SDW, and numbers of surviving spores were determined on the semiselective medium. This experiment was repeated three times.

\section{RESULTS}

Infectivity tests. At inoculum levels $\geq 1 \times$ $10^{6}$ conidia per $\mathrm{ml}$, all inoculated fern plants developed symptoms within 7 days. Below this concentration, an approximately linear decrease in disease incidence was observed at levels down to 100 conidia per ml (Fig. 1). No infections were observed when concentrations of conidia in the inoculum were below 100 conidia per $\mathrm{ml}$.

Semiselective medium. Of the four $C$. acutatum isolates tested, radial growth on benomyl-amended PDA was significantly less $(P=0.05)$ than growth on PDA, but all colonies grew and sporulated. However, no significant differences in growth were observed between the five levels of benomyl tested. After 5 days, colony diameter in the presence of benomyl decreased $63 \%$ $(4.19 \pm 0.42 \mathrm{~mm})$ compared to growth on PDA $(11.31 \pm 0.36 \mathrm{~mm})$. No significant differences in conidia germination were observed between PDA and benomylamended PDA $(1,000 \mu \mathrm{g} / \mathrm{ml})(99.50 \pm 0.62 \%$ and $99.50 \pm 0.43 \%$, respectively).

Survival of $C$. acutatum in soil and leaf debris. Populations of $C$. acutatum conidia recovered from laboratory soil tests decreased steadily, especially under moist or saturated conditions (Fig. 2). Within 1 week, detectable populations decreased by more than $30 \%$ for all treatments; within 4 weeks, numbers of viable conidia fell below 100 conidia per $g$ of soil with soil moistures $\geq 6 \%$ (we assumed that conidia were the $\mathrm{CFU}$ recovered). However, under dry conditions $(1 \%)$, it took 105 days for populations to fall below 100 conidia per $g$ of soil, but lower numbers of conidia could be recovered for up to 12 months. All reisolates of $C$. acutatum from soil maintained their pathogenicity toward leatherleaf fern and formed lesions within 2 weeks of inoculation.

When infected leaf debris was added to soil and incubated under controlled environmental conditions, concentrations of detectable conidia increased during the first week, except under very moist conditions (Fig. 3). However, long-term survival at various soil moistures followed a pattern similar to that observed for conidia directly added to soil. Nevertheless, the rate of decline was slightly less for soil-incorporated leaf debris: it required between 5 to 6 weeks for detectable populations to fall below 100 conidia per $\mathrm{g}$ for soil moistures $3 \%$

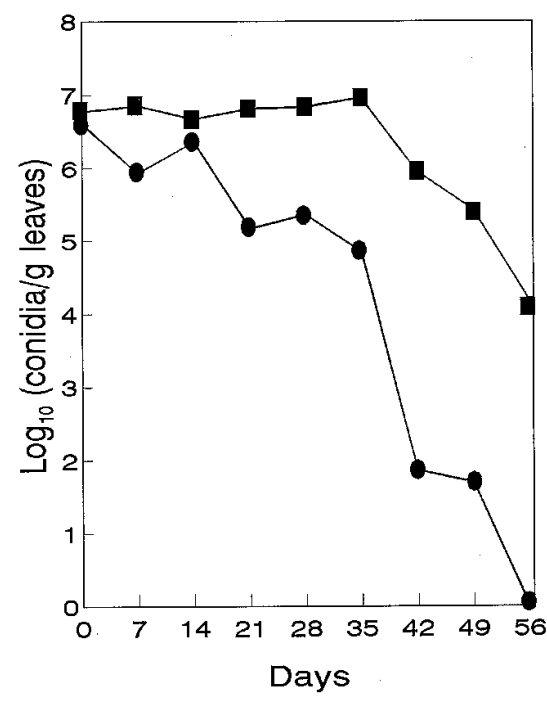

Fig 4. Number of Colletotrichum acutatum $\mathrm{CFU}$ recovered from air-dried $(\boldsymbol{\square})$ or dampened $(\bullet)$ diseased leaf debris maintained in the laboratory over a 56-day period. The temperature was maintained at $25^{\circ} \mathrm{C}$

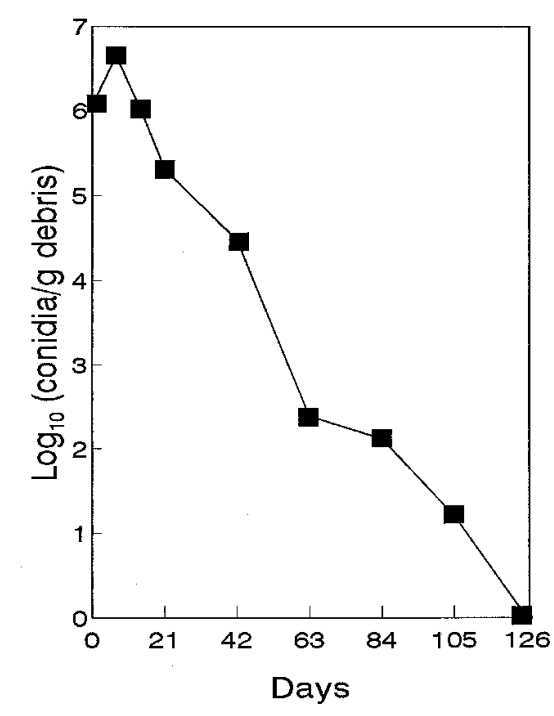

Fig 5. Number of Colletotrichum acutatum $\mathrm{CFU}$ recovered from diseased leaf debris buried in field plots over a 126-day period. and greater. Within dry soil (1\%), conidia associated with leaf debris maintained viability at levels above 100 conidia per $g$ for 31 weeks. Similar rates of decline in viable conidia also were observed when leaf debris without soil was stored in plastic containers under dry or moist conditions (Fig. 4).

Survival of $C$. acutatum in leaf debris buried outdoors in soil was similar to that in a controlled environment, in that initial populations increased within the first week and then steadily decreased over a 5-month period (Fig. 5). Viable conidia were detected from leaf debris samples until 126 days after incorporation in soil; however, the assumed inoculation threshold (100 conidia

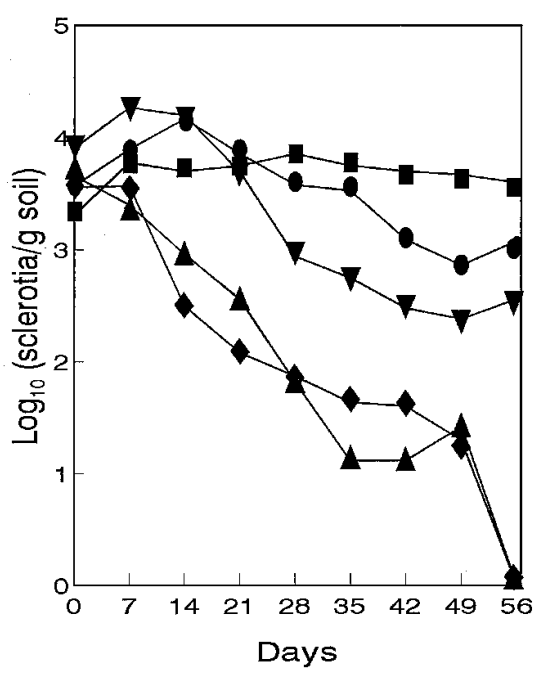

Fig. 6. Number of Colletotrichum acutatum sclerotia recovered from soil maintained in the laboratory at $25^{\circ} \mathrm{C}$ at $1(\boldsymbol{\square}), 3(\bullet), 6(\nabla), 12(\boldsymbol{\Delta})$, and $24 \%(\bullet)$ soil moisture over a 56 -day period.

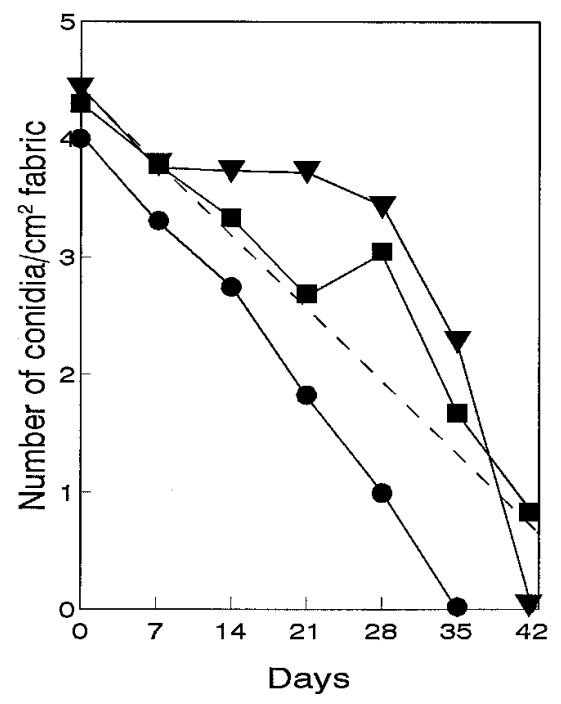

Fig. 7. Number of viable Colletotrichum acutatum conidia recovered after spray applications of $10^{6}$ conidia per $\mathrm{ml}$ to denim fabric maintained at $25^{\circ} \mathrm{C}$ over a 42 -day period. The solid lines indicate three separate experiments, and the dotted line represents the mean of these experiments. 
per $g$ of soil) was reached within 80 days after incorporation.

Sclerotia of $C$. acutatum added to soil held under laboratory conditions maintained high viability ( $\geq 100$ sclerotia per g of soil) under dry conditions for 26 weeks; however, under moist conditions $(\geq 12 \%)$, populations declined to very low levels by day 56 (Fig. 6). Viable sclerotia at lower numbers were recovered consistently from soil for up to 47 weeks after incorporation.

Survival of $\boldsymbol{C}$. acutatum on clothing. Numbers of viable conidia recovered from denim fabric held at $25^{\circ} \mathrm{C}$ and low humidity decreased at a steady rate (Fig. 7). Numbers of conidia sufficient to cause infection (100 CFU/ml) were recovered up to 4 weeks after placement on fabric, although some viable conidia were recovered for up to 42 days after treatment.

\section{DISCUSSION}

The number of conidia necessary for infection of leatherleaf fern under ideal conditions was determined to be approximately $100 \mathrm{CFU} / \mathrm{ml}$ in inoculum suspensions applied to fern leaves. With an estimate of the effective inoculum threshold needed for fern anthracnose and knowledge of initial conidia populations present, the survival rate of the pathogen in soil or leaf debris can be better estimated. These estimates are important for formulating disease management strategies and cultural controls. C. acutatum infects only immature fronds from the time they break the soil until they fully expand and mature; this interval ranges from 7 to 14 days depending on weather conditions (16). Acervuli can form on infected fronds within 3 to 4 days of infection, and conidia are washed or fall onto newly emerging fronds or onto soil. Once the disease is introduced into a production facility, the fungal life cycle becomes continuous, and subsequent disease losses can be extensive. The survival of conidia in soil and plant debris is important to formulation of disease management strategies, including decontamination of equipment and cultural control methods. When left for an extended time on PDA, C. acutatum produces sclerotia, which are especially common at acid $\mathrm{pH}$. The role, if any, that sclerotia play in survival of this fungus under normal field conditions is unknown, because sclerotia have been observed only under laboratory conditions.
Eastburn and Gubler (7) monitored the survival of $C$. acutatum in strawberry tissue over a 7 -week period at three temperatures $\left(11,25\right.$, and $\left.40^{\circ} \mathrm{C}\right)$ and three soil moistures (flooded, moist [10.6\%], and air dry). Recovery of $C$. acutatum from infected tissue declined rapidly under flooded soil conditions with soil temperatures $\geq 25^{\circ} \mathrm{C}$, whereas recovery from tissue samples was $100 \%$ after 7 weeks at 10 and $25^{\circ} \mathrm{C}$. Similar results were obtained in our study for survival of conidia, sclerotia, or conidia in infected leatherleaf fern debris under high and low soil moistures.

Fern harvesting occurs throughout the year and in all types of weather, including rainfall. Harvesters are contracted to work in different ferneries and may harvest in multiple fields and farms within the same day. Transport of conidia on clothing, tools, and equipment are thought to be major mechanisms by which the fungus has spread rapidly within and between ferneries (16). Wet clothing can easily adsorb hydrophilic spores that are later transferred onto the surfaces of susceptible leaves. Our results demonstrate that conidia also can persist on clothing for periods that provide excellent potential for long-distance transport and introduction into uninfested ferneries.

\section{ACKNOWLEDGMENTS}

This research was supported in part by the Fred C. Gloeckner Foundation Inc. and the Florida Department of Agriculture and Consumer Services.

\section{LITERATURE CITED}

1. Bernstein, B., Zehr, E. I., Dean, R. A., and Shabi, E. 1995. Characteristics of Colletotrichum from peach, apple, pecan, and other hosts. Plant Dis. 79:478-482.

2. Britton, K. O., and Redlin, S. C. 1995. Colletotrichum acutatum causes anthracnose of black gum (Nyssa sylvatica). Plant Dis. 79:1187.

3. Britton, K. O., and Redlin, S. C. 1995. Damping-off of flowering dogwood seedlings caused by Colletotrichum acutatum and Fusarium oxysporum. Plant Dis. 79:1188.

4. Chase, A. R. 1993. Diseases of leatherleaf fern and their control. Univ. Fla. Inst. Food Agric. Sci. Central Fla. Res. Edu. Center-Apopka Res. Rep. RH-93-18.

5. Coates, L. M., Erwin, J. A. G., and Muirhead, I. F. 1993. The use of a benomyl-resistant mutant to demonstrate latency of Colletotrichum gloeosporioides in avocado fruit. Aust. J. Agric. Res. 44:763-772.

6. Dillard, H. R., and Cobb, A. C. 1993. Survival of Colletotrichum lindemuthianum in bean debris in New York State. Plant Dis. 77:1233-1238.

7. Eastburn, D. M., and Gubler, W. D. 1990. Straw berry anthracnose: Detection and survival of Colletotrichum acutatum in soil. Plant Dis. 74:161-163.

8. Eastburn, D. M., and Gubler, W. D. 1992. Effect of soil moisture and temperature on the survival of Colletotrichum acutatum. Plant Dis. 76:841-842.

9. Farley, J. D. 1972. A selective medium for assay of Colletotrichum coccodes in soil. Phytopathology 62:1288-1293.

10. Hastie, A. C., and Georgopoulos, S. G. 1971. Mutational resistance to fungitoxic benzimidazole derivations in Aspergillus nidulans. J. Gen. Microbiol. 67:371-373.

11. Henz, G. P., Boiteux, L. S., and Lopes, C. A 1992. Outbreak of strawberry anthracnose caused by Colletotrichum acutatum in central Brazil. Plant Dis. 76:212.

12. Khan, M., and Sinclair, J. B. 1991. Effect of soil temperature on infection of soybean roots by sclerotia-forming isolates of Colletotrichum truncatum. Plant Dis. 75:282-285.

13. Nair, J., Newhook, F. J., and Corbin, J. B. 1983. Survival of Colletotrichum acutatum $\mathrm{f}$. sp. pinea in soil and pine debris. Trans. Br. Mycol. Soc. 81:53-63.

14. Stamps, R. H. 1992. Commercial leatherleaf fern culture in the United States of America. Pages 243-249 in: Fern Horticulture: Past, Present and Future Perspectives. Proc. Int. Symp. Cultivation Propagation Pteridophytes. Intercept Ltd., Andover, England.

15. Strandberg, J. O. 1994. Efficacy of selected fungicides for control of anthracnose in leatherleaf fern-A preliminary report. Univ. Fla. Inst. Food Agric. Sci. Central Fla. Res. Edu. Center. Cut Foliage Grower 9(11/12):1-4.

16. Strandberg, J. O., Stamps, R. H., and Norman, D. J. 1996. Fern anthracnose: A guide for effective disease management. Univ. Fla., Agric. Exp. Stn. Tech. Bull. 900.

17. Tu, J. C. 1983 Epidemiology of anthracnose caused by Colletotrichum lindemuthianum on white bean (Phaseolus vulgaris) in southern Ontario: Survival of the pathogen. Plant Dis. 67:402-404.

18. U.S. Department of Agriculture. 1993. Floriculture crops, summary. U.S. Department of Agriculture, Statistics Service, Agricultural Statistics Board, Washington, DC.

19. Vizvary, M. A., and Warren, H. L. 1982. Survival of Colletotrichum graminicola in soil Phytopathology 72:522-525.

20. Wilson, L. L., Madden, L. V., and Ellis, M. A. 1990. Influence of temperature and wetness duration on infection of immature and mature strawberry fruit by Colletotrichum acutatum. Phytopathology 80:111-116.

21. Wilson, L. L., Madden, L. V., and Ellis, M. A. 1992. Overwinter survival of Colletotrichum acutatum in infected strawberry fruit in Ohio. Plant Dis. 76:948-950.

22. Zulfiqar, M., Brlansky, R. H., and Timmer, L. W. 1996. Infection of flower and vegetative tissues of citrus by Colletotrichum acutatum and Colletotrichum gloeosporioides. Mycologia 88: 121-128. 